\title{
LITERATURE OF THE STUART SUCCESSION: AN ANTHOLOGY REVIEW
}

Marcela Santos Brigida

MCRAE, Andrew; WEST, John (Ed.). Literature of the Stuart successions: An anthology. Manchester: Manchester University Press, 2017.

After five years of research funded by the Arts and Humanities Research Council, Professors Andrew McRae and John West published Literature of the Stuart successions: An anthology in 2017. Led by researchers from the universities of Oxford and Exeter, The Stuarts Succession Project also produced an online, openaccess database for those interested in succession literature pertaining to the Stuart era in England (1603 - 1714). On their website, the scholars stress that the project was "conceived and developed in collaboration with the late Kevin Sharpe". Although Sharpe passed away "shortly after the grant was awarded, the project remains greatly indebted to his work and aims to honour his memory". It should be noted that Sharpe, who was the Director of the Centre for Renaissance and Early Modern Studies, Leverhulme Research Professor and Professor of Renaissance Studies at Queen Mary, University of London, was a great historian widely recognized for his work on the reign of Charles I. The professor's influence - and legacy - is strongly felt throughout the book. This anthology brings a myriad of texts ranging from poetry in the form of panegyrics, elegies, ballads and acrostics to "other types of writing and performance, including news reports, proclamations, speeches, pageantry, pamphlets and sermons" (p. 19). Literature of the Stuart successions thus presents itself as an invaluable research tool for literature and history scholars as well as for any reader interested in the history of English politics and cultural practices.

In the general introduction to the book, the reader is told that "the aim of this anthology is to represent both the breadth and the quality" (p. 19) of succession writing across the Stuart era, focusing on "literature produced in direct response to successions, as opposed to the ongoing debates associated with monarchy." (p. 31). In that sense, one might argue that McRae and West, as well as the other researchers involved in the project, were fully successful as they select, treat and present each text carefully and conscientiously. The anthology is presented in seven parts, each one dealing with a specific moment of succession throughout the turbulent and politically unstable seventeenth-century in England, one that saw a civil war, the decapitation of a king, the 
establishment of a republic as well as the restoration of monarchy after the Commonwealth invited Charles II to rule as king with power limited by Parliament. From when the first Stuart king rose to the throne - James I - in 1603 to the time the last Stuart queen - Anne - passed away childless thus ending the dynasty, England went through a major shift in the way it looked at power, the state, parliament and monarchy. Its tense relationship with Scotland is also illustrated throughout the text through shifting political alliances and the Stuart attempts to unify the crowns. All those tensions are presented and commented on through annotations that clarify and contextualize allusions made in the texts presented in this anthology. With short introductions to underline the political landscape of each succession, the book illustrates how the rise of print culture and newspapers created the conditions for the decline of poetry as a public form of writing throughout the seventeenth century. Therefore, when Anne rose to the throne in 1702, the reporting of a monarchic succession was not stated in the same way it would have been around the $1650 \mathrm{~s}$. The popularization of printed publication also evidenced the expansion of cultural activity beyond the court and, consequently, the decline of the power of censorship exercised by the monarch.

The texts presented throughout the anthology tell us something about the relationship between writers and their patrons at court, besides illustrating how alliances would vary according to shifts in power. After Elizabeth's death in 1603, poets were quick to mourn the last Tudor queen and praise her Stuart successor. In this particular context, we learn that Michael Drayton was frustrated in his attempt to press for advancement by writing the panegyric To the Majesty of King James (1603), while Sir John Davies was successful as his poems "The King's Welcome" and "To the Queen at the Same Time" (1603) were well received by James. We are also given the opportunity to look at poets we now regard as being among the greats of English literature in an unusual way. For instance, although Ben Jonson "would become the great court poet of the Jacobean period, in 1603 he was one of many young poets and playwrights desperate for preferment under the new regime." (p. 98). When the time came for a new Stuart king to rise to the throne in 1625 upon James's death, the tensions were much lower than they were in 1603 . The king had enough heirs to put people at ease in the matter of succession for the first time in over a hundred years. In that context, we are presented to John Donne as Dean of St Paul's Cathedral. More well-known as a metaphysical poet, a different, older and more mature face of Donne appears in The First Sermon Preached to King Charles (1625) presented a week after James's death. 
Also worthy of mention is the section dedicated to Oliver Cromwell's ascension to power and his installation as Lord Protector during the Interregnum. Although it was not a succession per se, it nevertheless made up an environment that was close enough to one to engender succession literature that was reflective of the tensions England was facing. The country was facing war with the Dutch while domestic conflicts in the form of royalist plots abounded. Furthermore, Cromwell's position as Lord Protector was a constant source of tension and discord, with royalists and republicans alike criticizing what they saw as a quasi-regal authority: "He was condemned as a tyrant, mocked as a false king and ridiculed for his appearance: Cromwell's nose was one of the most common features of satirical verse in the 1650s." (p. 150). Nevertheless, we learn that Cromwellian support was not scarce: besides John Dryden's Heroic Stanzas on the Death of Oliver Cromwell, the anthology includes Andrew Marvell's The First Anniversary of the Government under his Highness the Lord Protector (1655) and does not fail to mention John Milton's support of Charles's execution and the republic.

John Dryden is, evidently, one of the major examples of the unstable loyalties addressed by McRae and West. Poems written by him are featured in three different sections of the anthology. The fact that his political allegiances shifted radically throughout the second half of the seventeenth century was a source for harsh criticism. In 1659, Dryden praised Oliver Cromwell in an elegy after working for the Protectorate for at least two years. Nevertheless, he went on to become Poet Laureate under Charles II, thus praising not only the Stuart king, but the institution of monarchy as well. When he remained loyal to James II and refused to pledge allegiance to William III and Mary II upon the 1688 succession, he lost his position: "Dryden's silence, and the reversal of his political and poetic fortunes, was a cause for gleeful satire from Williamite poets" (p. 348). The criticism against Dryden's perceived inconstancy is addressed by the editors throughout the anthology, not only in the introduction to Dryden's poems that were included in it, but also in Thomas Shadwell's, The Address of John Dryden, Laureate to his Highness the Prince of Orange (1689). Published in a time where Dryden had recoiled from writing politically-charged poetry after refusing both to abandon his newfound catholic faith and to support The Glorious Revolution, The Address of John Dryden is a both retaliation against Dryden's poem Mac Flecknoe which had mocked Shadwell, and a "satirical take-down of a poet who had been the main defender of the Stuart monarchy for over a quarter of a century.” (p. 348). 
While McRae and West are to be praised for their fine selection of texts, they should also be applauded for their annotations. Most of the texts and poems included in their anthology receive this attentive treatment for the first time, such as Dryden's Heroic Stanzas on the Death of Oliver Cromwell (1659). Attention to detail and to subtlety in language and tone is key to fully grasping succession literature. Aphra Behn's texts are also given much attention by the scholars, who included two of her poems in the anthology. We learn that she was one of "the most prolific panegyrists of the later Stuart period." (p. 322). Although in 1685 she published poems about Charles II's death and James II's coronation, McRae and West elect A Poem Humbly Dedicated to the Great Pattern of Piety and Virtue Catherine Queen Dowager. On the Death of her Dear Lord and Husband King Charles II (1685), a poem dedicated to Charles's widow, the Portuguese princess Catherine of Braganza, as the "most striking" in its peculiarity, as "contrary to a king's elegy that could turn to a new monarch as a source of future hope, Behn's poem to Catherine is a reminder that such moments of loss may not, for all people, be overcome through the process and ceremony of succession". (p. 322). The second poem included reveal something about Behn's high status as a political writer as well as about her political allegiance. A Pindaric Poem to the Reverend Doctor Burnet, on the Honour he did me of Enquiring after me and my Muse (1689) was apparently written in response to Gilbert Burnet's request that Behn would write an ode praising the new king, William of Orange. Instead of doing so, she penned this poem echoing the "language of providence and conquest" (p. 342) from Burnet's sermons in what can be interpreted as satire. In it, she states her reasons for not writing a poem praising Orange.

Literature of the Stuart Successions: An Anthology is a fantastic source of information, offering a solid critical framework for any reader, student, professor or scholar interested in Early Modern England. While the focus of the anthology are texts produced in the centre of political power in the Stuart era, that is, mostly London, those are also reflective of the tensions between England and its neighbours, especially Scotland, the land where the Stuart dynasty came from, and Ireland, where political and religious tensions remained alight throughout the successions. This was a dynasty that began with the ascension of a Scottish king to the English throne who hoped, but ultimately failed, to unite the crowns. It ended in 1714 with the death of a protestant queen who became the first occupant of the unified throne of Great Britain as the Treaty of Union was passed by the parliaments of England and Scotland in 1707. In many 
ways, the seventeenth century and its political instabilities, religious tensions and problematic successions helped forge the political system Britain enjoys today, as power slowly, but steadily shifted away from the hands of the monarch towards Parliament. The poems and texts carefully selected to compose this anthology, as well as the vast material made available on The Stuarts Succession Project online database are reflective of all those changes in the mindset of the English people. Furthermore, the scholars' approaches to those texts help us approach history - literary and otherwise wish a fresh outlook. On their website, the project team state that they looked at a "wide range of printed sources" aiming to shed light on the "largely neglected body of succession literature in seventeenth-century Britain". They sought to "understand how writers responded to unpredictable moments of political change" and to "uncover the ways their work helped to shape political personalities, ideas, and actions across a century of unprecedented and violent upheaval". In that sense, the anthology that condenses the results of that laborious enterprise is brilliantly reflective of their endeavour. It comes as a must-read, a companion to anyone wishing to grasp what defines succession literature as a genre and why the Stuart era was so intensely defined and portrayed by it.

\section{References}

KEWES, Paulina; MCRAE, Andrew; WEST, John. The Stuart Successions Project. Available at: http://stuarts.exeter.ac.uk/. Accessed: 10 Sep. 2018. 